\title{
Representações do sujeito poético lésbico
}

\author{
Representations of the Lesbian Poetic Subject \\ Representaciones del sujeto poético lesbiano \\ Ágnes Christiane de Souza*
}

\section{Resumo}

Ao escrever "Heterossexualidade compulsória e existência lésbica", a feminista radical e ativista lésbica Adrienne Rich pontua, entre tantas colocações pertinentes, a presença da marca da dupla subjetividade no corpo político da mulher lésbica. Ela é uma mulher, sujeito menor diante de uma sociedade patriarcal e misógina, e ela é lésbica em uma sociedade que, além do que já foi posto, é lesbofóbica e fetichista. Passa-se o tempo e a poeta lésbica Angélica Freitas nos/se pergunta: "para que serve um útero quando não se faz filhos?". Em consonância, a poeta carioca Simone Brantes dá a voz a um eu lírico que questiona: "como entram duas vulvas sob a colcha?". O mesmo pensamento de uma sociedade capitalista que vê o útero da mulher como uma fábrica a serviço dela é a mesma que deslegitima, fetichiza, oprime e tenta apagar o afeto, o amor, a história e a memória na relação entre duas mulheres. O presente trabalho pretende pontuar como o amor entre lésbicas é também resistência política, e como o sujeito poético lésbico - e de autoria lésbica - é importante para esse movimento. Para tal, serão analisadas obras das poetas supracitadas, Angélica Freitas e Simone Brantes, a fim refletir sobre gênero, sexualidade, subjetividades do sujeito lésbico e enriquecer a discussão acerca desses sujeitos que passam constantemente por diversos processos de apagamento.

Palavras-chave: lésbica, representações, sujeito poético.

\begin{abstract}
Writing about "Compulsory Heterosexuality and Lesbian Existence", the radical feminist and lesbian activist Adrienne Rich call attention to the double subjectivity of the lesbian woman's political body. As a woman she is seen as a minor figure in a patriarchal and misogynistic society, and as a lesbian in a society that is additionally lesbophobic and fetishist. Years later, the lesbian poet Angélica Freitas asks us: "What is the use of a womb when it isn't to make kids?". Accordingly, the poet Simone Brantes, from Rio de Janeiro, gives voice to a lyrical self who asks: "how do two vulvas fit under the bedspread?". The same thought of a capitalist society that sees women's womb as an industry at her service is the same one that delegitimizes, fetishes, oppresses and try to erase affection, love, history and memory of a relationship between two women. This work aims to point out how love between lesbians is also political resistance, and how the lesbian poetic subject - of lesbian authorship - is important to this movement. For this, works of the aforementioned authors, Angélica Freitas and Simone Brantes, will be analyzed to reflect on gender, sexuality, subjectivities of the lesbian
\end{abstract}

\section{Resumen}

$\mathrm{Al}$ escribir "Heterossexualidade compulsória e existência lésbica", la feminista radical y activista lesbiana Adrienne Rich puntúa, entre muchas colocaciones pertinentes, la presencia de la doble marca de subjetividad en el cuerpo político de la mujer lesbiana. Ella es una mujer, sujeto más pequeño ante una sociedad patriarcal y misógina, y ella es lesbiana en una sociedad que, además de lo que ya ha sido, es lesbianofóbica, y fetichista. El tiempo pasa y la poeta lesbiana Angélica Freitas nos/ se pregunta: “ ¿De qué sirve un útero cuando no tienes hijos?". En consonancia, la poeta carioca Simone Brantes da la voz a un yo poético que cuestiona: " ¿Cómo entran dos vulvas debajo de la manta?". La misma idea de una sociedad capitalista que ve el útero de una mujer como fábrica a su servicio es la misma que ilegitima, fetichiza, oprime y trata de borrar el afecto, el amor, la historia y la memoria en la relación entre dos mujeres. El presente trabajo pretende señalar cómo el amor entre lesbianas es también resistencia política, y como sujeto poético lesbiano -y de autoría lesbianaes importante para este movimiento. Con este fin, se analizarán las obras de las poetas antes mencionadas, Angélica Freitas e Simone Brantes, para reflexionar sobre género, sexualidad,

\footnotetext{
"Universidade Federal de Pernambuco (UFPE), Recife, PE, Brasil. Đorcid.org/0000-0002-4969-2672. E-mail: ag.acsouza@ gmail.com
} 
subject, and contribute to the discussion about these subjects that often pass through many processes of erasure.

Keywords: lesbian, representations, poetic subject. subjetividades del sujeto lesbiano y enriquecer la discusión sobre estos sujetos que pasan constantemente por varios procesos de borrado.

Palabras-clave: lesbiana, representaciones, sujeto poético.

\section{Sujeito poético lésbico}

Não é de hoje, como bem aponta Silvia Federici (2017), que o trabalho da mulher é invisibilizado nas conjunturas e sistemas construídos para produção de capital e de conhecimento, bem como não é de hoje que mulheres que têm em si a dupla marca da subjetividade, por serem mulheres e lésbicas, são diariamente ignoradas e apagadas das histórias, das historiografias e das literaturas. Neste artigo, proponho-me a mostrar como, apesar desse contexto supracitado, poetas lésbicas estão escrevendo sobre seus afetos, seu erotismo, suas formas de fazer política, ou seja, estão contando suas próprias histórias.

Dividida em três partes, a discussão tem como corpus as obras Um útero é do tamanho de um punho (2017), da poeta Angélica Freitas, e Quase todas as manhãs (2016), da poeta Simone Brantes. A escolha do corpus, bem como das poetas, diz respeito a escritas que falam abertamente sobre relações entre mulheres, sem que haja algum tipo de ruído relacionado ao que se está querendo dizer e quem está dizendo, pois se trata de duas poetas lésbicas escrevendo poesia de autoria lésbica. $\mathrm{O}$ assumir-se como lésbica a fim de ocupar lugares, vozes e posturas tanto literariamente quanto socialmente vem a ser o primeiro ponto de embate e discussão aqui proposto. O segundo ponto procura levantar questões acerca da heterossexualidade compulsória e o heterossexismo sofrido por mulheres, bem como explanar como se dão esses fenômenos para que siga a manutenção de poder. O terceiro e último ponto adentra as questões das análises dos poemas a fim de desenvolver de forma mais empírica as teorias anteriormente comentadas, bem como questões suscitadas pelos poemas, como a fetichização das relações lésbicas, a deslegitimação de sua sexualidade e de seu erotismo e seus afetos. Como anuncia o título deste artigo, procurou-se observar como essas poetas falam desses sujeitos lésbicos em seus poemas e como, a partir deles, estão agregando e aumentando referências as essas mulheres tão ausentes de referências.

\section{Eu sou uma poeta lésbica}

Em seu ensaio intitulado "To(o) queer the writer - loca, escritora, y chicana", a escritora Gloria Anzaldúa (2009, p. 164) coloca:

Meu rotular a mim mesma é para que a Chicana e lésbica e todas as outras pessoas em mim não sejam apagadas, omitidas, ou assassinadas. Nomear é como eu faço minha presença conhecida, como afirmo quem e o que eu sou e como quero ser conhecida. Nomear a mim mesma é uma tática de sobrevivência. ${ }^{1}$

Ao colocar entre as necessidades supracitadas a do ato de se autorrotular, a autora assinala uma luta ainda constante da comunidade LGBTQI+: a de manter-se viva, nomear a si mesma como uma tática de sobrevivência, de não apagamento, de representatividade política e social. Saliento, principalmente, um ponto que norteará este e os demais pontos, que é o movimento de ir de encontro à tentativa secular de apagamento de mulheres lésbicas. Apesar de a "escrita lésbica" ser um ponto de crítica neste ensaio de Gloria Anzaldúa, em função do risco que se corre em ser reducionista e homogeneizante com o adjetivo, é a partir dele, e das mais diversas formas de se referir às mulheres lésbicas, que conseguimos retirar de uma espécie de névoa que se situam as formas de representar esses sujeitos na poesia.

\footnotetext{
${ }^{1}$ Tradução de Tatiana Nascimento.
} 
A escrita de si aparece como uma aliada às produções de literatura de autoria LGBTQI+. Além das questões já postas por Anzaldúa, acrescento a fala de Larissa Pelúcio, em seu ensaio "Subalterno quem, cara pálida? Apontamentos às margens sobre pós-colonialismos, feminismos e estudos queer":

Anunciar o lugar de fala significa muito em termos epistemológicos, porque rompe não só com aquela ciência que esconde seu narrador, como denuncia que essa forma de produzir conhecimento é geocêntrica, e se consolidou a partir da desqualificação de outros sistemas simbólicos e de produção de saberes (Pelúcio, 2012, p. 398-399).

É a partir dessa autoenunciação que podemos tentar entender de onde parte e para onde parte o discurso proferido por esses sujeitos. Aqui, especificamente, sujeitos ainda considerados marginalizados e desviantes. Em decorrência desse movimento, mas não só, é possível perceber posicionamentos sociais e políticos, bem como formas de organizações de resistência diante de uma estrutura patriarcal, heteronormativa e branca. Apesar de a autora apontar para uma perspectiva mais antropológica e filosófica, podemos observar esse movimento também nas literaturas.

A escrita de si torna-se, assim, um foco de interesse para os estudos literários, porque redimensiona a base interpretativa dessa discussão, trazendo à baila um conteúdo de uma forma de narrar não inéditas, mas com grande projeção no campo representacional da literatura e exibidos constantemente pelas mídias. Essa escrita valoriza personagens que são projeções verossímeis de sujeitos focalizados por várias políticas públicas. Como a literatura tem a capacidade de fazer transitar em seus espaços os tipos sociais, as personagens "encarnam" os vários modelos de pessoas com as quais convivemos na vida chamada real; e, no âmbito da diversidade, elas, as personagens - gays, lésbicas ou queer -, são, ou estão, nas estórias construídas (Silva, 2016, p. 96-97).

Quando Silva fala de uma forma de narrar que não é inédita e de apropriar-se dela para contar suas próprias histórias e as histórias dos seus, ele fala indiretamente de uma atitude queer diante do que já está estabelecido como formas de narrar. A diferença é que a história que será lida partirá de vozes situadas em uma minoria histórica e politicamente apagadas, que vêm lutando por brechas na produção literária para falar de suas subjetividades e idiossincrasias além de uma ótica estereotipada, como aponta Regina Dalcastagnè:

A vida dos grupos marginalizados tende a ser representada à distância, de forma "monocromática" - como diria Löic Wacquant (2001, p. 7) - e estética. Normalmente, seus integrantes nos são apresentados ou como vítimas do sistema ou como aberrações violentas. No entanto, sob uma perspectiva menos autocentrada, é possível vislumbrar, entre eles, uma infinidade de estratégias de resistência e de deslocamento, ou tentativas de deslocamento, no espaço social (Dalcastagnè, 2017, p. 49).

E em um segundo momento:

Quando entendemos a literatura como uma forma de representação, espaço onde interesses e perspectivas sociais interagem e se entrechocam, não podemos deixar de indagar quem é, afinal, esse outro, que posição lhe é reservada na sociedade, e o que seu silêncio esconde. Por isso, cada vez mais, os estudos literários (e o próprio fazer literário) se preocupam com os problemas ligados ao acesso à voz e à representação dos múltiplos grupos sociais. Ou seja, eles se tornam mais consciente das dificuldades associadas ao lugar da fala: quem fala e em nome de quem. Ao mesmo tempo, discutem-se as questões correlatas, embora não idênticas, da legitimidade e da autoridade (palavra que, não por acaso, possui a mesma raiz de autoria) na representação literária. Tudo isso se traduz no crescente debate sobre o espaço, na literatura brasileira e em outras, dos grupos marginalizados - entendidos, em sentido amplo, como todos aqueles que vivenciam uma identidade coletiva, que recebe valoração negativa da cultura dominante -, que sejam definidos por sexo, etnia, cor, orientação sexual, posição nas relações de produção, condição física ou outro critério (Dalcastagnè, 2017, p. 17).

A autora toca em pontos que se faz necessário sinalizar. Primeiro, em ambas as citações, há preocupação com o "acesso à voz", visto que há uma cultura de proliferação de estereótipos a respeito das representações de minorias. Como exemplo, a imagem da mulher lésbica 
amargurada e histérica, à qual se refere Rich ao contestar a imagem que a heterossexualidade compulsória constrói da lésbica. Segundo, fala-se de uma consciência que precisa estar costurada à literatura, ou seja, é preciso fazer uma retrospectiva e entender a força da literatura nas sociedades. Com isso, é possível perceber como a circulação de materiais desconexos com essa força corrobora para o apagamento e silenciamento dos que sempre foram negados à história, nesse caso, produções literárias produzidas por minorias. Quando a autora refere-se ao "que seu silêncio esconde", é por conta da negação do direito à voz mencionada anteriormente.

E, por último, é importante perceber como o falar de si engendra formas de resistência às caricaturas. Quando uma autora lésbica fala de seus afetos, de suas relações sexuais, de seus desejos, de suas práticas cotidianas, ela rompe com o silêncio, com as especulações e, principalmente, abre caminhos para que outras autoras lésbicas sintam-se à vontade de narrar suas histórias. Uma, depois outra, e outra, e outra, desnaturalizando o status da invisibilidade lésbica na literatura. A resistência a que Regina Dalcastagnè se refere é a de seguir produzindo, organizando-se, "incomodando" e contestando a norma, dizendo "eu e os meus existimos, continuaremos contando nossas histórias", "Daí os ruídos e o desconforto causado pela intrusão dessas vozes não autorizadas no campo literário" (Dalcastagnè, 2017, p. 50).

\section{Amar e agir contra a corrente}

Em seu mais recente lançamento, Aos outros só atiro o meu corpo, a poeta carioca e artista plástica lésbica, Maria Isabel Iorio, diz-nos, em um poema breve, as seguintes palavras: "2. Uma mulher sobre outra mulher/não é preliminar é/histórico" (Iorio, 2019, p. 55), e apresenta o panorama das relações lésbicas com o que Butler (2003) chamaria de pré-discursivo. Em contrapartida, tomando um pouco de distância dos versos supracitados, temos uma redundante história de apagamento histórico das relações afetivas e eróticas das mulheres lésbicas. Antes de adentrar nos (de)méritos do apagamento histórico, é necessário pensarmos na carga subjetiva engendrada nesses sujeitos, visto que vivemos em uma sociedade (ainda) extremamente patriarcal, machista, misógina, heterossexual e racista. Transitamos, apesar de nossas bolhas, em um mundo em que qualquer tipo de comportamento que não se encaixe ou se negue a ser assimilado por esse "grupo" supracitado é convidado a se retirar, seja de um local, seja da própria história.

Há um modus operandi que "justifica" os recorrentes apagamentos e silenciamentos no que tange à existência lésbica: a heterossexualidade compulsória. Em uma abordagem bastante didática, em seu Queer: um aprendizado pela diferença, Richard Miskolci (2014) apresenta o fenômeno da heterossexualidade compulsória como um modelo imposto, ou seja, não se tem a opção de não ser ou não corroborar com o modelo heterossexual. Mas quem impõe esse modelo? O mesmo grupo que citei no parágrafo anterior, homens heterossexuais, cisgênero, brancos de classe abastadas, ou o que Landowski (2002) chamaria de "grupo de referência".

Antes de Miskolci, Adrienne Rich já fazia suas considerações acerca da heterossexualidade compulsória, debruçando-se sobre a temática atrelada ao apagamento da existência lésbica. No ensaio "Heterossexualidade compulsória e existência lésbica", ela debate e questiona o poder do patriarcado sobre as mulheres não necessariamente lésbicas, mas que em algum grau sofrem cerceamentos por parte dos homens, elaborando categorias em cima da teoria de Kathleen Gough, as quais chamou de "características do poder masculino". Estas somam oito características, das quais aqui seleciono algumas:

1. de negar às mulheres [sua própria] sexualidade - [por meio de clitoridectomia e infibulação; de cintos de castidade; de punição, inclusive com a morte, para o adultério por parte das mulheres; a punição, inclusive com a morte, para a sexualidade lésbica; de negação psicanalítica do clitóris; da repressão da masturbação; da negação da sensualidade maternal e pós-menopáusica; da histerectomia desnecessária; de imagens pseudolésbicas nos meios de comunicação e na literatura; do fechamento de arquivos de destruição de documentos relacionados à existência lésbica]

2. ou de impor-lhes [a sexualidade masculina] - por meio de estupro (inclusive o estupro marital) [...] das representações pornográficas de mulheres respondendo com prazer à 
violência e à humilhação sexual (com a mensagem subliminar de que a heterossexualidade sádica é mais "normal" do que a sensualidade entre mulheres)] [...]

7. de restringir sua criatividade - [caça às bruxas como as campanhas contra as parteiras e curandeiras, e com pogroms contra mulheres independentes e "não assimiladas", a definição de ocupação dos homens como mais valiosas que as das mulheres em qualquer cultura, a fim de que os valores culturais se tornem a personificação da subjetividade masculina; a restrição da realização pessoal das mulheres ao casamento e à maternidade; a exploração sexual das mulheres por artistas e professores homens; a interrupção social e econômica das mulheres; o apagamento da tradição das mulheres] (Rich, 2019, p. 44-47). ${ }^{2}$

As características levantadas por Gough, e desenvolvidas por Rich, mostram a amplitude do controle dos homens sobre as mulheres. Nas três características que destaquei, é possível perceber os diversos caminhos de cerceamento que o comportamento masculino pode tomar para manter o que, em sua concepção, é normal: mutilar mulheres, negando-lhes do direito de sentir prazer com outras mulheres ou sozinha através da masturbação ou objetos de prazer; impor-lhes a sexualidade masculina, sem pudores, a fim de hierarquizar sexualidades colocando a sua como única e indiscutível; ou, ainda, privando-lhes do direito de desenvolvimento artístico e cultural.

De modo mais específico, resolvi salientar essas três características porque contemplam situações ainda recorrentes quando se fala de mulheres lésbicas, como a mutilação genital, o estupro corretivo e o apagamento de tradição. Esses três pontos desenvolvidos e tocados por Rich contemplam de forma lúcida ações micro ou macros da heterossexualidade compulsória e do apagamento da existência lésbica historicamente.

Algumas das formas pelas quais o poder dos homens se manifesta demonstram mais claramente do que outras a imposição da heterossexualidade às mulheres. Mas cada uma daquelas que enumerei se soma ao conjunto de forças dentro de que as mulheres têm sido convencidas que o casamento e a orientação sexual são componentes inevitáveis de suas vidas, mesmo quando insatisfatórios e opressores. O cinto de castidade; o casamento precoce; o apagamento da existência lésbica (exceto como exótica e perversa) na arte, literatura e no cinema; a idealização do amor romântico e do casamento heterossexual são algumas formas bastante óbvias de compulsão, as duas primeiras exemplificando a força física, e as duas seguintes, o controle da consciência (Rich, 2019, p. 48).

Apesar de não usar essa palavra, na citação acima, Rich nos diz que o fenômeno da heterossexualidade compulsória age em prol de uma manutenção de seus privilégios. A mulher é para casar, enquanto a lésbica é pintada como um sujeito exótico, alheio e, comumente falado, "mal amado". Porém, o maior medo dessas pessoas que as controla, seja fisicamente ou psicologicamente, é que elas se amem entre si. Há um pavor no amor, no erótico, no sensual, na ligação emocional entre duas mulheres. Diante de tudo isso, onde estão essas mulheres? $\mathrm{Na}$ literatura brasileira, por exemplo, a pesquisadora Regina Dalcastagnè $(2012$, p. 167) fez um levantamento da orientação sexual dos personagens do romance brasileiro contemporâneo, no qual apenas 3,9\% se referia a homossexuais. Quanto desses 3,9\% pode ser atribuído às representações de sujeitos lésbicos na ficção?

Além da heterossexualidade compulsória presente nas sociedades como forma de manutenção de privilégios, também se pode encontrar o fenômeno do "heterossexismo", que, segundo Miskolci, corrobora com a visão de uma sociedade homogênea e heterossexual. Segundo o autor, o "heterossexismo é a pressuposição de que todos são, ou deveriam ser, heterossexuais. Um exemplo de heterossexismo está nos materiais didáticos que mostram apenas casais formados por um homem e uma mulher" (Miskolci, 2012, p. 43).

Assim como Dalcastagnè e Miskolci, Funck também questiona quais tipos de representação de mulheres estão presentes em textos literários escritos por mulheres, partindo do princípio de que a "primeira mulher" é a autora:

\footnotetext{
${ }^{2}$ Os textos em itálico são as categorias listadas por Kathleen Gough e os situados nos colchete são elaborações de Adrienne Rich.
} 
A segunda mulher está nos textos. E é a política de sua representação que nos interessa na medida em que, imaginada, ela é da maior importância na construção dos sistemas a partir dos quais nos subjetivamos. Se somos as histórias que nos contam - tanto no sentido de que elas nos representam quanto no de que são contadas para nós - então as narrativas podem se tornar uma fonte de identificação (Funck, 2011, p. 72).

A autora faz um apontamento essencial, apesar de trazer como referência a mulher sem marcas subjetivas, para refletir a questão da existência lésbica nos textos literários: "se somos a histórias que nos contam [...] então as narrativas podem se tornar uma fonte de identificação". Pergunto-me, então, onde mulheres lésbicas encontram fontes de identificação? Bem, já sabemos que não é nos livros didáticos. Seria, talvez, no esmiuçar dos 3,9\%?

A existência lésbica compreende tanto a quebra de um tabu quanto a rejeição de um modo de vida compulsório. Também é um ataque direto ou indireto ao direito dos homens de acesso às mulheres. Mas é mais do que isso, embora comecemos a percebê-lo primeiro como uma forma de dizer não ao patriarcado, um ato de resistência. Isso inclui, claro, o isolamento, o ódio a si mesmas, crises, alcoolismo, suicídio e violência entre mulheres; romantizamos por nossa própria conta e risco o que significa amar e agir contra a corrente, e com pesadas punições; e a existência lésbica tem sido vivida (ao contrário, por exemplo, da existência judaica ou católica) sem a cesso a qualquer conhecimento de uma tradição, uma continuidade ou um esteio social. A destruição dos registros, da memória e das cartas que documentavam as realidades da existência lésbica deve ser seriamente vista como uma forma de manter a heterossexualidade compulsória para as mulheres - já que a alegria, a sensualidade, a coragem e a comunidade é que foram alijadas do nosso conhecimento bem como a culpa, a autonegação e a dor (Rich, 2019, p. 66-67).

O que Rich reflete, antes de tudo, é que, apesar de toda tentativa de apagamento e silenciamento, a existência lésbica é algo que sempre houve e sempre haverá, indo de encontro ao senso comum da heterossexualidade compulsória. Ademais, ela frisa as complexidades de um sujeito com dupla marca de subjetividade, imerso em um modelo de sociedade patriarcal em que mulheres estão sempre situadas perifericamente. Mas o que mais me toca pessoalmente e como pesquisadora, na fala de Rich, é o fato de a existência lésbica ter de estar a todo o momento tentando recuperar e manter tradições, pois, como já dito anteriormente, o apagamento social é revertido em apagamento histórico.

A resistência em dar continuidade a projetos (ou mesmo criar), seja na literatura, no cinema, no teatro, na música e de organização entre si, como se pode perceber, nos mais diversos coletivos que vêm surgindo e somando forças aos mais variados movimentos lésbicos, é um desdobramento e uma junção de percepções de que é preciso fazer: escrever e contar histórias de mulheres lésbicas que contribuíram para o não apagamento da existência lésbica, bem como viver uma vida de afetos, de erotismo, de política, de cultura com referências lésbicas sem um viés de exceção, sem precisar contar nos dedos de uma mão suas referências de escritoras, cineastas, atrizes, dançarinas, professoras, artistas plásticas e cantoras lésbicas.

\section{Duas moças se encontram...}

Diante das reflexões feitas nos tópicos anteriores, interessa-nos saber como as poetas lésbicas aqui estudadas armam-se contra uma sociedade patriarcal que tenta invisibilizá-las culturalmente, historicamente e literariamente. Para tal, retomarei alguns aspectos teóricos supracitados, bem como serão inseridos alguns outros a fim de complementar o fio do raciocínio até aqui construído. Comecemos com um poema da obra Um útero é do tamanho de um punho, de Angélica Freitas:

mulher de vermelho

o que será que ela quer

essa mulher de vermelho

alguma coisa ela quer

pra ter posto esse vestido 


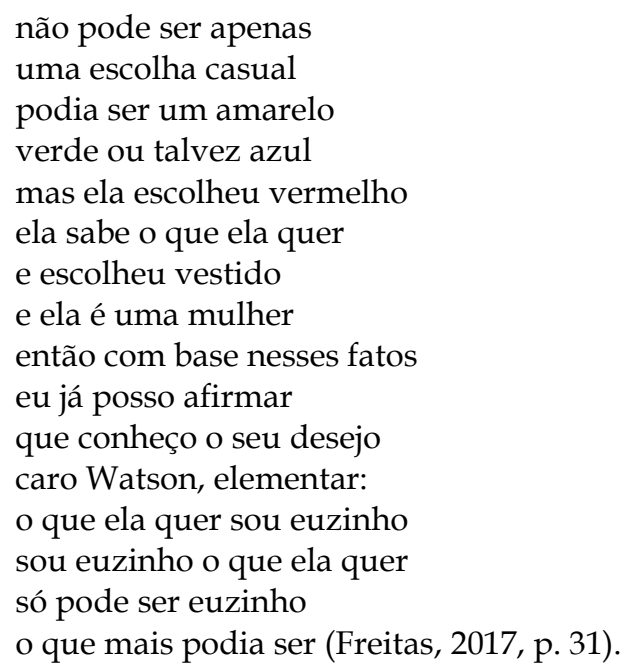

E um que integra Quase todas as noites, da poeta carioca Simone Brantes:

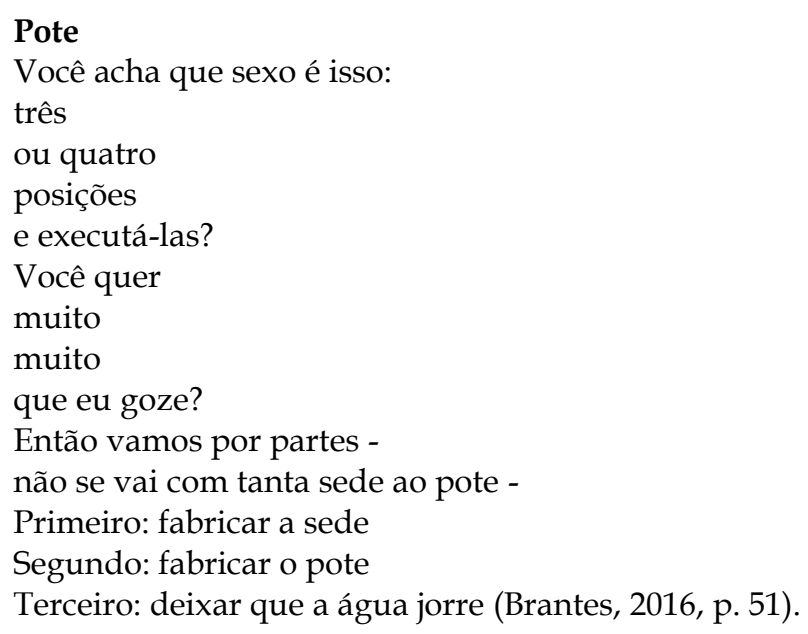

Os dois poemas trazem a figura do homem com um sujeito equivocado em duas relações díspares, a primeira, no poema de Freitas, a poeta ironiza o discurso recorrente do homem-cisheterossexual em se manter no centro do ir e vir no que se refere às mulheres. $O$ tom de superioridade e certeza de que mulheres só agem com a finalidade de agradar o macho aparece em negrito por conta do significado atrelado à cor vermelha, à sensualidade, à sexualidade, à voluptuosidade, à sedução, entre outras leituras que apontam para o contexto da luxúria, como se pode ver nesses versos :"alguma coisa ela quer / pra ter posto esse vestido / não pode ser apenas / uma escolha casual / podia ser um amarelo verde ou talvez azul / mas ela escolheu vermelho".

O poema põe em questão "o que ela quer", o que este sujeito, sendo uma mulher, quer ao trajar um vestido vermelho, e em nenhum momento esse eu lírico masculino reflete qualquer finalidade que não seja ele mesmo. A pobreza de ligação das "evidências", ao inserir o personagem Watson, de Sherlock Holmes, o faz concluir o que é, para ele, o óbvio, a única razão pela qual uma mulher veste um vestido vermelho é para agradar-provocar os homens. Esta finalidade, como os "argumentos" da heterossexualidade compulsória tem amparo tanto na história quando na literatura, como coloca Rich nesta passagem:

A mentira tem muitas camadas. Na tradição Ocidental, uma camada - a romântica afirma que as mulheres se sentem inevitavelmente, até precipitadamente e tragicamente, atraídas por homens; que até mesmo quando essa atração é suicida (por exemplo, Tristão e Isolda, O Despertar de Kate Chopin), ainda é um imperativo orgânico (Rich, 2019, p. 81).

O segundo poema, como já havia adiantado, também versa criticamente sobre a posição do homem como centro de tudo em diversos âmbitos das nossas vivências sociais, porém, 
diferentemente do primeiro, o eu lírico se dirige a um receptor que dialoga com engessamento das possibilidades em sentir prazer. Esse engessamento, muitas vezes, advindo das performances naturalizadas da indústria pornô, ou do que a mulher pode ou não pode fazer quando transa ou do que deve ou não deve fazer. Pode-se ver, no primeiro verso que compõe o poema, uma provocação por parte do eu lírico ao dizer "Você acha que sexo é isso", e em seguida deslegitima ao automatismo das relações sexuais: "três / ou quatro / posições / e executá-las?".

Além da crítica ao automatismo e da deslegitimação do funcionamento uniforme dos corpos nos momentos das relações sexuais, o poema gira em torno de uma esfera de desejo. Há provocação por via de ensinamentos por parte do eu lírico, que ensina a outra pessoa que é preciso desejo, calma e parcimônia no momento de relação entre os corpos, como nos versos que se seguem: "Você quer / muito / muito / que eu goze? Então vamos por partes?". Em vez de entrar em um âmbito de didatismo, entramos no âmbito da sedução, do desejo, como se estivéssemos sendo guiados pelo eu lírico a fim de seu gozo. É por meio dele, do eu lírico, que nós e o outro indivíduo somos envolvidos por um desejo que precisa ser construído por etapas, que tentamos aprender que precisamos de muito mais que três ou quatro posições para fazer com que a água do pote jorre.

Aproveitando o gancho dado por Brantes, entrarei no segundo "bloco" de poemas das autoras que se interseccionam em sua temática a fim de inserir em suas poéticas o que Gloria Anzaldúa chama de não neutralidade do texto. Partimos para um dos pontos em que as mulheres lésbicas são mais atacadas: seu sexo, seu erotismo, seu desejo por outras mulheres. Primeiro, um poema breve de Freitas intitulado "mulher de respeito", "diz-me com quem te deitas / angélica Freitas" (Freitas, 2017, p. 31). Segundo, "As moças" de Brantes:

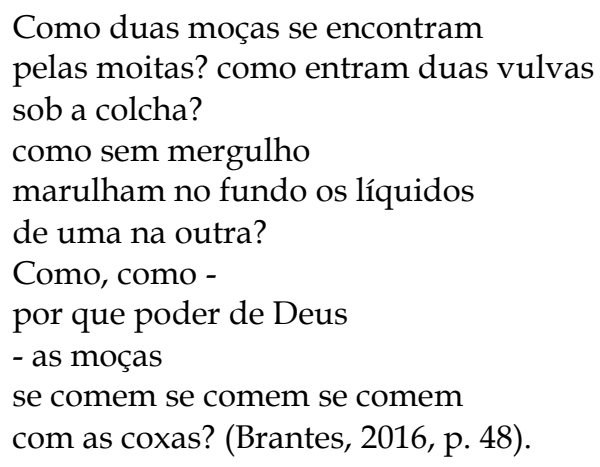

Em ambos os poemas há indivíduos que se intrometem nas situações a fim de deslegitimar as experiências e práticas sexuais de mulheres lésbicas, bem como anular seu erotismo e desejo. $\mathrm{O}$ poema de Angélica é curto e assertivo, pois denota uma série de questionamos, por exemplo: o que seria uma mulher de respeito? O que essa mulher deveria fazer (ou não fazer) para sê-lo? O que influencia no merecimento de respeito e/ou na sua adjetivação com quem esta mulher se deita? A resposta a esta última pergunta seria: tudo. Há constante vigilância para com quem mulheres se deitam, principalmente se existe a suspeita de que esta mulher se deita com outras mulheres. A "preocupação" é com a destruição da matriz familiar heteronormativa formada pela equação homem + mulher e que a partir dessa soma surjam os belos frutos dessa união, os filhos, estes que perpetuarão o nome e os bons costumes dessa família de respeito, e assim segue o fluxo "sem fim".

A mulher deitar com outra mulher não está nos planos desse grupo. Ademais, é impossível não recordar do que Judith Butler, na leitura de Sara Salih (2015), e posteriormente Paul B. Preciado (2014) falaram sobre o falo lésbico, bem como a deslegitimação do sexo lésbico por conta da ausência de um pênis, erroneamente atrelado ao falo, um objeto fantasma e simbólico que só existe na linguagem. Reconhecer, legitimar o sexo lésbico é acreditar na possibilidade de reterritorialização do falo a fim de desprivilegiá-lo, bem como reconhecer a presença do erotismo e dos afetos na relação entre mulheres.

A identificação com as mulheres é uma fonte de energia, uma fonte potencial de seu poder, cerceada e contida sob a instituição da heterossexualidade. A negação da realidade e a visibilidade da paixão das mulheres por outras mulheres, da escolha de aliadas de mulheres pelas mulheres, de companheiras de vida e de comunidade, a obrigação de que essas 
relações sejam dissimuladas e a sua desintegração sob pressão intensa têm significado uma perda incalculável para o poder de todas as mulheres de mudar as relações sociais entre os sexos, para libertarmos a nós mesmas e umas às outras (Rich, 2019, p. 81).

O que Rich coloca, na citação acima, diz respeito ao potencial dos encontros entre duas mulheres seja de forma afetiva, sexual ou política. Esse encontro, ou como a autora coloca, essa "fonte de energia" é o que mais assusta a equivocada estabilidade patriarcal e heterossexual presente em sociedade. É através também desse "pavor" que a tentativa de apagamento das mulheres lésbicas e suas relações eróticas e afetivas se dão na história. Como a autora aponta, "a existência lésbica sugere tanto o fato da presença histórica de lésbicas quanto da nossa criação contínua do significado dessa existência" (Rich, 2019, p. 65), ou seja, sem uma construção contínua de um lugar na história sem que esta seja destruída não é possível que haja existência lésbica tampouco presença histórica de mulheres lésbicas. Contam-se histórias, falam-se de grandes artistas, escritoras, pintoras, artesãs, mas onde estão registradas as histórias dessas mulheres? Onde podemos encontrá-las em meio a uma história que tem a face de um homem heterossexual, branco e ocidental?

$\mathrm{O}$ que comumente encontramos aparece nesses dois poemas de Freitas, em que a autora ironiza como a sociedade enxerga as mulheres de modo que as classifica como boas, limpas, sujas, brabas, fetichizadas ou invisíveis.

porque uma mulher boa

é uma mulher limpa

e se ela é uma mulher limpa

ela é uma mulher boa

há milhões, milhões de anos

pôs-se sobre duas patas

a mulher era braba e suja

braba e suja e ladrava

porque uma mulher braba

não é uma mulher boa

e uma mulher boa

é uma mulher limpa

há milhões, milhões de anos

pôs-se sobre duas patas

não ladrava mais, é mansa

é mansa e boa e limpa (Freitas, 2017, p. 11).

V.

eu tive uma namorada

com superpoderes

de invisibilidade

e quando andava com ela

também era invisível

mas quando ela usava

uma blusa transparente

virava a incrível

mulher-teta

eu continuava

sob o guarda-chuva

de superpoderes

superinvisível

invejável

ao lado das 
cervejas e

superamendoins (Freitas, 2017, p. 86-87).

A poeta, por meio do artífice da ironia, mostra duas opiniões que dominam o senso comum nos poemas reproduzidos aqui na íntegra. A primeira é de que há um padrão físico, de que há prérequisitos para ser considerada uma "mulher de verdade", no caso, uma mulher limpa, pois uma mulher limpa é uma mulher boa. E uma mulher que não é boa ou limpa sequer é considerada mulher. Ao usar o verbo "ladrar" e o adjetivo "mansa" a autora aproxima a mulher a um animal, a um bicho de estimação que foi domesticado. O que chega a nossos olhos, em uma definição irônica, mas com respaldo do senso comum, é que, para ser mulher, é preciso limpeza, e isso inclui pelos, hábitos, modos, bem como não ladrar e ser mansa, ou seja, uma mulher silenciada e domesticada. Existe um padrão de uma mulher boa, e essa mulher não é uma mulher lésbica.

A segunda opinião aparece em uma espécie de depoimento dado por uma das partes de um casal de mulheres lésbicas e, nesse depoimento, ela relata os superpoderes que sua namorada adquire ao entrar nos padrões do que é ser uma mulher "de verdade". Mas, além disso, o eu lírico coloca sob nossos olhos a fetichização sofrida por sua namorada. Ainda nos primeiros versos a autora sutilmente fala da invisibilidade das mulheres lésbicas na sociedade: "eu tive uma namorada /com superpoderes / de invisibilidade/e quando andava com ela / também era invisível". Saliento os dois últimos versos em que o eu lírico expõe um superpoder que nada mais é do que o olhar - ou a falta dele - que a sociedade lança sobre essas relações, mas que muda quando uma das partes utiliza uma blusa transparente, quando seu corpo, momentaneamente, se encaixa no ideal de mulher, quando seu corpo performa feminilidade. A namorada do eu lírico não deixou de ser lésbica, o eu lírico não deixou de ser lésbica, mas a fetichização dos corpos que performam feminilidade e passabilidade "transformam" uma lésbica em uma mulher digna de ser olhada e desejada. Afinal, segundo o senso comum, uma lésbica não é uma mulher, ela é invisível para sociedade, ela é invisível para a história.

\section{Considerações finais}

Nesse breve espaço procurei enxergar as obras das poetas Angélica Freitas e Simone Brantes de forma abrangente e interpretadas sob a perspectiva de como enxergo o sujeito poético lésbico, ou sujeitos poéticos lésbicos, assim no plural. Busquei destacar a importância de uma autoria como lugar de fala, de mulheres lésbicas contarem histórias de outras mulheres lésbicas, pois seja de forma política, romântica, erótica ou irônica, essas mulheres estão presentes na literatura. Pensar essa autonomeação também faz parte de um processo de análise para evitar ruídos e interpretações equivocadas, além de, como já dito, salientar a presença recorrente de uma escrita autodiegética na literatura de autoria queer.

Além disso, é preciso entender qual o lugar que mulheres lésbicas ocupam na história, como consumimos seus trabalhos, como as lemos, como assistimos, onde estão essas mulheres que carregam em si a dupla (às vezes tripla) marca da subjetividade. Não é possível, ainda mais nos tempos que estamos pensando, ignorar as estruturas estabelecidas de poder que tentam silenciar e apagar mulheres lésbicas que não têm em si a passabilidade e a performatividade do que a sociedade entende como mulher. Os sujeitos narrados por Freitas e Brantes não são assimiláveis e, como esta última diz em um dos seus poemas: "Não há tempo para duas mulheres /e um homem de permeio" (Brantes, 2016, p. 76).

\section{Referências}

ANZALDÚA, Gloria (2009). To(o) queer the writer - loca, escritora, y chicana. In: KEATING, AnaLouise (Ed.). The Gloria Anzaldúa reader. Durham: Duke University Press. p. 163-175.

BRANTES, Simone (2016). Quase todas as noites. Rio de Janeiro: 7Letras. 
BUTLER, Judith (2003). Problemas de gênero: feminismo e subversão da identidade. Rio de Janeiro: Civilização Brasileira.

DALCASTAGNÈ, Regina (2012). Literatura brasileira contemporânea: um território contestado. Vinhedo: Horizonte.

FEDERICI, Silvia (2017). Calibã e a bruxa: mulheres, corpo e acumulação primitiva. Tradução DE coletivo Sycorax. São Paulo: Elefante.

FREITAS, Angelica (2017). Um útero é do tamanho de um punho. São Paulo: Cia das Letras.

FUNCK, Susana Bornéo (2011). O que é uma mulher. Revista Cerrados, Brasília, v. 20, n. 31, p. 64-74.

IORIO, Maria Isabel (20196). Aos outros só atiro o meu corpo. Bragança Paulista, SP: Urutau.

LANDOWSKI, Erick (2002). Presenças do outro: ensaios sobre sociossemiótica. São Paulo: Perspectiva.

MISKOLCI, Richard (2014). Teoria queer: um aprendizado pela diferença. Belo Horizonte: Autêntica.

PELÚCIO, Larissa (2012). Subalterno quem, cara pálida? Apontamentos às margens sobre pós-colonialismos, feminismos e estudos queer. Contemporânea, v. 2, n. 2, Dossiê Saberes Subalternos, p. 395-418, jul./dez.

PRECIADO, Paul B. (2014). Manifesto contrassexual: práticas subversivas de identidade sexual. São Paulo: n-1 edições.

RICH, Adrienne. Heterossexualidade compulsória e existência lésbica \& outros ensaios. Rio de Janeiro: A Bolha, 2019.

SALIH, Sara (2015). Judith Butler e a teoria queer. Belo Horizonte: Autêntica.

SILVA, Antonio de Pádua Dias da (2016). Literatura de língua portuguesa e homoafetividade: o aspecto político na ficção contemporânea. In: CAMARGO, Fábio Figueiredo; GARCIA, Paulo César (Org.). Homocultura e linguagens. Salvador: Eduneb. 